\title{
Marco Maulu, La cerva bianca e la fata. Dal 'récit bref' al romanzo cavalleresco
}

Paola Cifarelli

\section{CpenEdition}

\section{Journals}

Édition électronique

URL : https://journals.openedition.org/studifrancesi/4578

DOI : 10.4000/studifrancesi.4578

ISSN : 2427-5856

Éditeur

Rosenberg \& Sellier

\section{Édition imprimée}

Date de publication : 1 avril 2012

Pagination : 117

ISSN : 0039-2944

\section{Référence électronique}

Paola Cifarelli, « Marco Maulu, La cerva bianca e la fata. Dal 'récit bref' al romanzo cavalleresco », Studi Francesi [En ligne], 166 (I | LVI) | 2012, mis en ligne le 30 novembre 2015, consulté le 19 novembre 2021. URL : http://journals.openedition.org/studifrancesi/4578 ; DOI : https://doi.org/10.4000/ studifrancesi.4578

Ce document a été généré automatiquement le 19 novembre 2021.

\section{(c)}

Studi Francesi è distribuita con Licenza Creative Commons Attribuzione - Non commerciale - Non opere derivate 4.0 Internazionale. 


\title{
Marco Maulu, La cerva bianca e la fata. Dal 'récit bref' al romanzo cavalleresco
}

\author{
Paola Cifarelli
}

\section{RÉFÉRENCE}

MARCo MAULu, La cerva bianca e la fata. Dal 'récit bref' al romanzo cavalleresco, «Reinardus», 22, 2010, pp. 76-103.

1 Le ms Florence, Biblioteca Nazionale Centrale II.II.28 conserve la Legenda e storia di messere Prodesagio, texte florentin en prose datable de la fin du XIV siècle. Les rapports avec le lai de Guigemar de Marie de France sont réexaminés ici à la lumière de récentes études sur l'origine du lai et ses rapports avec la tradition celtique, ce qui permet à l'A. de prouver que surtout la seconde partie de la version italienne présente des affinités avec le texte de Marie. 